\title{
CURRENT ISSUES \\ IN FAMILY BUSINESS MANAGEMENT
}

VyARA KYUROVA, ${ }^{1}$ BLAGOVESTA KOYUNDZHIYSKA-DAVIDKOVA ${ }^{2}$

RECEIVED

ACCEPTED

JEL

CLASSIFICATION

KEYWORDS

ABSTRACT
South-West University „Neofit Rilski” Blagoevgrad, BULGARIA.

1e-mail: verivasileva@abv.bg

2e-mail: vesi_8808@abv.bg

25 February 2017

15 May 2017

L26, D22, M21

family business, management, problems, strategy, plan

Management takes an important place in the activity of enterprises, including the family ones. One of the important requirements for effective management of the family business is its good structure and focus on higher business goals. Some of these goals are maximizing profits improvement of the strategy, job creation, qualification of staff and care for the interests of all shareholders and partners. In this regard, the objective of this article is to clarify the problems in the management of family business. Analysis and conclusions on the issue are based on data from a survey of 186 family businesses located in the Southwest Planning Region in Bulgaria. Based on the analysis and evaluation of results the major problems and generalized conclusions are outlined.

\section{Introduction}

The family business has a key economic and social importance in Bulgaria. It contributes to the gross domestic product and the flexibility of the market. With its help new jobs are created and local, regional and national development is accelerated. Furthermore, the implementation of effective management of this business has a decisive influence on the productivity of research from its activities. The management of the family business is 
characterized by striving for independence and full control over the activities (Madgerova, 2012, p. 20). Madgerova and Kyurova emphasize that because of the intertwining of interests and issues of family and business, management is informal. The same authors believe that it reflects the long-term interests of the family in the sphere of business (Madgerova, Kyurova, 2012, p. 27). Obviously, in today's dynamic environment proper management of the family business is essential for survival and development of the family business and the economy of the country. Moreover, implementation of the management function allows not only to achieve high efficiency in the operations of the business, but also to increase its competitiveness (Madgerova, 2013, p. 190). Therefore, sustainable development of family business can be achieved provided that it is competitive. In this regard Johannison (2000) emphasizes that the competitiveness of the family business is based on a combination of long-term planning of company activities, functional family group and professional management. At the same time well-grounded strategy is key to creating a sustainable family business and achieving competitive advantage. According to Paleshutski (1994, p. 54) there is a very important relationship, namely, the governance structure of the company must be a derivative of its strategy. The author believes that before forming a strategy, it is necessary to create the potential for its development, and then - if necessary - to modify the potential for realization of the strategy (Paleshutski, 1994, p. 54). Furthermore, it should be borne in mind that planning is a core function of management. In this regard Madgerova claims that there is a close relationship and dependence between planning and other functions of management (Madgerova, 2012, p. 95).

For proper and efficient management of the family business, several conditions need to be met. First is the shared responsibility among partners and managers of businesses (Duke, Armeni, Makraken, Terzieva, Dakovska, 2013, p. 20). Moreover, secondly, effective management requires the establishment of family policy. This policy is intended to help avoid decisions on arbitration, which are usually considered for granted within the family business (Picard, 2004). The third point is about taking responsibility. Most of the representatives of the family business believe they are not responsible to anyone, but it is quite a wrong idea because each family member should be responsible for their actions before the rest of the family and the business. On this basis the three dimensions of management of the family business are formed and each of these dimensions should be accountable to others. These dimensions form the so-called Three Cycle Model. A review of the scientific literature shows that a number of studies dedicated to managing family businesses are based precisely on this model. For example, Gersick, Davis, Hampton and Lansberg (1997, pp. 5-6) state that the three cycle model describes the family business system with three independent but overlapping subsystems - business, property and family. A similar opinion is the one of Todorov claiming that the model of family business is composed of three independent but overlapping subsystems: business, ownership and family (Todorov, 2011, p. 169). According to Yordanova, the management bodies in the family firm are based on the same three subsystems - owned company and family (Yordanova, 2014, p. 32). Each of these three subsystems has its own management bodies, and through them the company achieves its goals. The three subsystems are involved in creating plans to achieve these goals. According to Poza and Daugherty (2014, p. 9) three cycle model suggests that the family company is best understood and studied as a complex and dynamic social system in which integration is achieved through reciprocal adjustments between the subsystems. For this reason, the subsystem "family" is expected to have a strong impact on the subsystems "ownership" and "management" and vice versa. Understanding them is possible only when all three subsystems with their interactions and interdependencies are studied as one system (Poza, Daugherty, 2014, p. 9). 
In Bulgaria the management of the family business is a relatively little analyzed question. In this context, the objective of this paper is to outline the problems in the management of the family business throughout the Southwestern planning region and to suggest directions for their solution.

\section{Methodology}

This study has used the primary data. The primary data was collected through a survey, which was distributed to 186 family businesses. The survey was a sample one of representative character and includes the enterprises from the three main areas of activity - manufacturing, trade and services. Direct survey in which respondents themselves fill in the questionnaire was used as a data collection method.

The study was limited in time and place. The survey was conducted between May and August 2016 in Southwestern planning region in Bulgaria. Statistical methods were used to analyze and evaluate the results obtained in the study as the observation method and the method of grouping, the method of analysis, table method.

Using questionnaire as research instrument enables the collection and analysis of quantative data using descriptive statistics. Data were collected from these enterprises using an own questionnaire, which included also Likert-scale questions, due to the fact that it corresponds to a high degree to the goals set for this current research.

\section{Resullts and Discussion}

The first part of the study is aimed at establishing the actual status of the companies according to their size, the control of the enterprise, characteristics for the development of family business, family relationships, etc. The distribution of the companies according to their size is of big importance. Micro enterprises have the largest share $-68.82 \%$. A significantly lower proportion of is of small enterprises $-27.96 \%$, followed by medium $-2.15 \%$. Only $1.08 \%$ of the surveyed enterprises did not answer this question.

Another interesting question is if the control of the company was entrusted in the hands of a non-family member in family businesses would be successful or not. It was found that a significant proportion of the respondents (73.12\%) think that under this condition, the business would not be successful. A good share of respondents (25.81\%), however, argue that it would be. Only $1.08 \%$ did not answer this question.

Several characteristics such as ownership, succession, management, or a combination of the three, are crucial to the development of a family business. The largest proportion of respondents (79.57\%) gave the answer „all of these". With relatively low share of those who consider crucial to the development of family business is the management (11.83\%), followed by those who say response "property" (4.3\%) and "continuity" (3.23\%). Only 1.08\% did not answer this question.

In terms of the question whether family relationships influence or not the effective management of business for 69.89 percent of the respondents these relationships influence and to $30.11 \%$ they do not influence.

The answers to a question related to whether the education / professional qualification of the person filling out the survey corresponds to the sphere in which the enterprise operates revealed that for 56.99 percent it matches, while for $40.86 \%$ it does not coincide. Only $2.15 \%$ of respondents did not answer this question.

In connection with the efficient management of the activities of the family business an important issue is that of the managerial skills of the owner (manager) of the company. Almost all of them have such skills - in $94.62 \%$ of the enterprises. Only $4.3 \%$ have no skills and only $1.08 \%$ of the enterprises did not answer this question. 
The second group of questions in the survey are aimed at identifying strategies implemented by family businesses. As regards the existence of a strategy for development, a significant proportion of the respondents (76.34\%) claim to have developed and implemented one. A relatively low proportion of respondents do not have a development strategy $-22.58 \%$. Only $1.08 \%$ of the enterprises have not responded to this question. Another question regards the strategies that family business applies. The data presented in Table. 1 shows that the highest proportion of enterprises apply a strategy of "high quality" $-63.44 \%$, followed by those that implement the "customer care" strategy $-52.69 \%$, and third ranks the strategy "low prices" $-41.94 \%$. With equal share at the fourth place follow enterprises applying the strategy of "minimum cost" and "staff care" $(29.03 \%)$ and the share is that of the ones that apply "product differentiation" is $23.66 \%$. A slightly lower share of enterprises apply the strategy of "special products" (16.13\%) and "total quality management" (10.75\%). A relatively low proportion of enterprises have not responded to this question $-3.23 \%$, and only $1.08 \%$ is the percentage of those who indicated the answer "other".

Table 1. Distribution of respondents' answers about the strategies implemented by the family business

\begin{tabular}{lc}
\hline \multicolumn{1}{c}{ Strategies implemented in the enterprises } & Share of respondents, \% \\
\hline Product differentiation & 23.66 \\
Minimum costs & 29.03 \\
Low price & 41.94 \\
Customer care & 52.69 \\
Staff care & 29.03 \\
Total quality management & 10.75 \\
High quality & 63.44 \\
Specialized products & 16.13 \\
Other & 1.08 \\
No answer & 3.23 \\
\hline
\end{tabular}

Source: authors' own research.

An important aspect of the study is the evaluation of activities related to planning. In support of this is the opinion of Livens that no family company can exist and prosper without planning (2007, p. 7). In this regard, Marinova points out that in the planning process the goals of the enterprise and the activities that need to be implemented to achieve these goals are determined (Chausheva, Rafailova, Boyadzhieva, Marinova, Yankova, Lindner, Georgieva Tarneva, Voynova, 2008, p. 24). The survey results show that a significant proportion of respondents have a plan for development $-76.34 \%$, and $22.58 \%$ have not developed such a plan. A small proportion of respondents have not given an answer $-1.08 \%$.

Further analysis of the survey results reveals the opinion of the representatives of the family business's with respect to the ability to adapt to changes in market conditions. In this regard, the largest percentage of respondents consider this ability as good. Their share ranges from $39.78 \%$ in 2011 to $45.16 \%$ for 2015 .

The surveyed representatives of family businesses assess the level of qualification and experience of the owner/owners of the undertaking as very good. The most significant share of respondents gave this assessment in 2014 and 2015 - with an equal share of 53.76 percent. In 2013 this share was $48.39 \%$ and in 2012 it decreased to $43.01 \%$. For 2011 , this percentage is $41.94 \%$.

In terms of assessing the quality of the development strategies of the business, it was found that respondents define it as good. The highest proportion of respondents who assigned a good score on this indicator was in 2014 
$-40.86 \%$, followed by equal share in 2011 and $2013-39.78 \%$. For 2012, their share was $38.71 \%$, and for 2015 $-37.63 \%$. The lowest proportion is of respondents who assess the quality of the development strategies of the enterprise as excellent. Their share ranges from 2.15 to $4.3 \%$.

It is necessary to consider that the experience of family business in management is an important prerequisite for its effective functioning. In this regard, the survey data show that the largest share of respondents assess this experience as good. Their share is between 26.88 and $34.41 \%$. It is noteworthy that smallest proportion is of those who define this experience as excellent - from 1.08 to $4.3 \%$.

The survey results show that the main problems in the management of the family business can be summarized as follows:

- insufficiently effective is the process of managing the family business, which is mainly due to the fact that very few of the representatives of this business have excellent experience in business management and the necessary qualifications,

- the importance of plans and strategies for successful business management has not yet been realized and therefore a significant part of the respondents do not develop and implement plans and strategies,

- family businesses are not paying enough attention to the quality of the development strategies of the enterprise,

- family businesses still do not realize the important role and the special attention that must be paid to each of the three subsystems in three cycle management model. Timely awareness of their interconnection and interdependence would contribute to the successful existence and continuity of this type of business.

\section{Conclusions}

The survey results reveal that at this stage, management of the business in the family enterprises is not effective. An important prerequisite for its solution is the implementation of timely planning and strategies by family businesses. In turn, this will contribute to better development of this business in the long term, to its better market positioning and success in business. Furthermore, the three cycle model and especially understanding of the complexity within the three different systems (ownership, family, business) makes it possible to perceive the complexity that exists within the family business. This can be achieved by identifying the expectations, motivations, fears and intentions of individuals in the specific family business.

To run a successful family business one need to learn from the beginning how to manage, understand what is happening and how to deal with different interests through the development of management strategies.

\section{References}

Chausheva, V., Rafailova, G., Boyadjieva E. Marinova, E., lankova, I., Lindner, J., Georgieva, K., Tarneva, T. \& Voynova, H. (2008). Economics of the enterprise. Sofia: Dionysus (in Bulgarian).

Duke, M., Armenia, L., Makraken, K., Terzieva, L. \& Dakovska, M. (2013). Manual management and best practices in the field of family business. "Znanie" Sofia and the Maltese Association of Family Business (in Bulgarian).

Gersick, K., Davis, J., Hampton, M. \& Lansberg, I. (1997). Generation to generation. Life Cycles of the Family Business. Boston, Massachusetts: Harvard Business School Press.

Johannison, B. (2000). Modernising the industrial district-rejuvenation or managerial colonization. In: M. Taylor, E. Vatne (eds.), The networked firm in a global world. Small firms in new environments. Aldershot.

Livens, J. (2007). Management of family firms. Zahariy Stoyanov (in Bulgarian). 
Madgerova, R., Georgiev, G., Karashtranova, E., Kyurova, V., Terziyska, I., Stavrova, E. \& Dimitrova, R. (2012). Organization and management of small businesses. Blagoevgrad: Langov (in Bulgarian).

Madgerova, R. (2013). Economic and social dimensions of entrepreneurship. Blagoevgrad: University Publishing House "Neofit Rilski" (in Bulgarian).

Madgerova, R. \& Kyurova, V. (2012). Condition, characteristics and problems of family entrepreneurship. In: Entrepreneurship and Economics (pp. 20-32). Blagoevgrad: University Publishing House "Neofit Rilski” (in Bulgarian).

Paleshutski, K. (1994). Management - experience of leading companies in the world. Blagoevgrad: Fortune (in Bulgarian).

Picard, D. (2004). CFIB Research - Business Transition. Available at: http://www.cfib.ca/research/reports/succession_0405_e.pdf.

Poza, E. \& Daugherty, M. (2014). Family Business. South-Western, a part of Cengage Learning.

Todorov, K. (2011). Part I. Fundamentals. Starting a new business. Sofia: BARMP (in Bulgarian).

Yoradanova, D. (2014). Management and development of a family firm. Sofia: University Publishing House "St. Kliment Ohridski" (in Bulgarian).

Cite this article aS: Kyurova, V., Koyundzhiyska-Davidkova, B. (2017). Current issues in family business management. European Journal of Service Management, 22 (2), 47-52. DOI: 10.18276/ejsm.2017.22-06. 